\title{
P-0831- Association between Socioeconomic Status and Risk of Incident Diabetes in Adults Residing in Urban Delhi
}

Kanika Agarwal ${ }^{1}$, Roopa Shivshankar ${ }^{2}$, Mohammed K Ali ${ }^{3}, \mathrm{KM}_{\text {Venkat Narayan }}{ }^{3}$, Dorairaj Prabhakaran ${ }^{2}$, Ravinder Chadha ${ }^{1}$, Nikhil Tandon ${ }^{4}$

${ }^{1}$ Department of Food and Nutrition, Lady Irwin College, University of Delhi, India ${ }^{2}$ Centre for Chronic Disease Control, Public Health Foundation of India, New Delhi, India

${ }^{3}$ Rollins School of Public Health, Emory University, Atlanta, United States of America

${ }^{4}$ Department of Endocrinology and Metabolism, All India Institute of Medical Sciences, New Delhi, India

\section{Background}

In developed countries, a lower socioeconomic status (SES) is associated with an increased risk of diabetes, while, in developing countries such as India, affluent people are found to be at a higher risk. With increasing urbanization, rural-to-urban migration, and change in lifestyle (e.g., high calorie diet, physical inactivity, etc.), the risk of diabetes is also increasing among people in lower SES.

\section{Aim}

To assess the association between socioeconomic status and risk of incident diabetes in adults.

\section{Methods}

Study Design and Locale- Matched case control study, within the Cardio-metabolic Risk Reduction in South Asia (CARRS) cohort, a longitudinal study among non-pregnant adults $\geq 20$ years, representative of urban Delhi. Data from the study were available from baseline evaluation and an annual follow up for the first two years, with clinical and biochemical evaluation performed at baseline and after 2 years; and only a clinical evaluation at year 1 of follow up.

Sample Size- 100 adults newly diagnosed with diabetes (fasting blood glucose $\geq 126 \mathrm{mg} / \mathrm{dl}$ or $\mathrm{HbA}_{1} \mathrm{c} \geq 6.5 \%$ ) and 200 age and gender matched controls (diabetes free individuals at baseline and till the second annual visit)

\section{Data Collected-}

- Socio economic status- was assessed by educational qualifications, occupation, and income of the participants

- Anthropometric measurements- Height (stadiometer), Weight (weighing scale), and Body Mass Index (BMI)

- Questionnaire- Family history of diabetes, tobacco and alcohol consumption

- International Physical Activity Questionnaire (IPAQ- short form)

\section{Statistical Analysis-}

- Analyzed data using Stata version 11 and a 5\% level of significance was considered

- Applied univariate conditional logistic regression analysis

- Applied conditional logistic regression with and without adjustment for covariates

\section{Results}

The difference in distribution of education, occupation, and income classes across cases and controls were found to be statistically insignificant
Table 1: Association between SES Status and Risk of Type 2 Diabetes

\begin{tabular}{|c|c|c|c|c|}
\hline & \multicolumn{2}{|c|}{ Model 1 ${ }^{\#}$} & \multicolumn{2}{|c|}{ Model $2^{\#}$} \\
\hline Variables & $\begin{array}{c}\text { OR } \\
(95 \% \mathrm{CI}) \\
\end{array}$ & p-value & $\begin{array}{c}\text { OR } \\
(95 \% \mathrm{CI}) \\
\end{array}$ & p-value \\
\hline \multicolumn{5}{|c|}{ Educational Qualification } \\
\hline $\begin{array}{l}\text { Primary school } \\
\text { and below }\end{array}$ & $\begin{array}{c}0.952 \\
(0.445,2.035)\end{array}$ & 0.8981 & $\begin{array}{c}1.400 \\
(0.402,4.871)\end{array}$ & 0.5969 \\
\hline $\begin{array}{l}\text { High or } \\
\text { secondary } \\
\text { school }\end{array}$ & $\begin{array}{c}1.246 \\
(0.700,2.217)\end{array}$ & 0.4555 & $\begin{array}{c}1.561 \\
(0.630, \quad 3.870)\end{array}$ & 0.3365 \\
\hline $\begin{array}{l}\text { Graduate or } \\
\text { higher }\end{array}$ & 1.000 & & 1.000 & \\
\hline \multicolumn{5}{|c|}{ Family Income (Rs/month) } \\
\hline$<10,000$ & $\begin{array}{c}0.682 \\
(0.316,1.470)\end{array}$ & 0.3290 & $\begin{array}{c}0.856 \\
(0.242, \quad 3.029)\end{array}$ & 0.8097 \\
\hline $10,000-30,000$ & $\begin{array}{c}1.199 \\
(0.594,2.421)\end{array}$ & 0.6127 & $\begin{array}{c}1.532 \\
(0.510,4.606)\end{array}$ & 0.4472 \\
\hline $30,000-50,000$ & $\begin{array}{c}1.195 \\
(0.485,2.943)\end{array}$ & 0.6989 & $\begin{array}{c}1.854 \\
(0.528, \quad 6.510)\end{array}$ & 0.3351 \\
\hline$\geq 50,000$ & 1.000 & & 1.000 & \\
\hline \multicolumn{5}{|l|}{ Occupation } \\
\hline Not working & $\begin{array}{c}1.679 \\
(0.718,3.922)\end{array}$ & 0.2316 & $\begin{array}{c}1.407 \\
(0.396,4.996)\end{array}$ & 0.5977 \\
\hline $\begin{array}{l}\text { Semi or } \\
\text { unskilled worker }\end{array}$ & $\begin{array}{c}1.049 \\
(0.482,2.285)\end{array}$ & 0.9043 & $\begin{array}{c}2.444 \\
(0.676,8.835)\end{array}$ & 0.1729 \\
\hline Skilled worker & $\begin{array}{c}1.400 \\
(0.600,3.264)\end{array}$ & 0.4360 & $\begin{array}{c}2.217 \\
(0.659, .458)\end{array}$ & 0.1982 \\
\hline White collar & 1.000 & & 1.000 & \\
\hline
\end{tabular}

\#Model 1- individual univariate crude model for each variable, Model 2: Multivariate model, adjusted for body mass index (continuous), family history of diabetes (yes vs no), physical activity score (continuous), duration of tobacco use (continuous) and alcohol consumption (yes vs no)

\section{Discussion}

Our results show that the lower educational attainment / income, and/or non-white collar occupation is associated with risk of diabetes, similar to observed in the more affluent socio economic group. Until recently, the affluent in the country were thought to be at a higher risk of diabetes. However, we find that the risk of diabetes is becoming independent of the socioeconomic status. Therefore, the healthcare policies to prevent diabetes should evenly focus across all strata of the society.
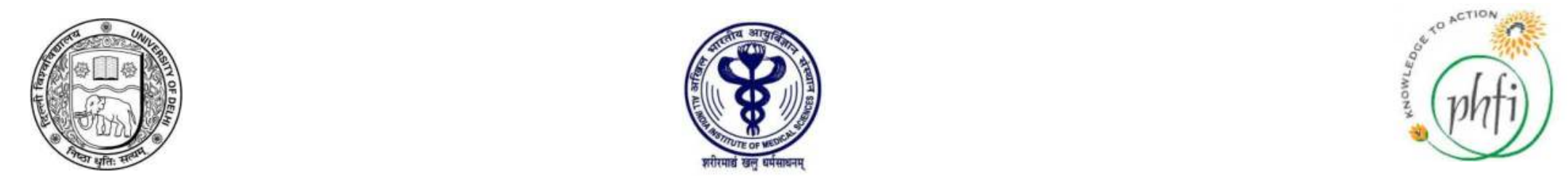
$\bigotimes$ EMORY $\begin{aligned} & \text { ROLLINS } \\ & \text { SCHOLO OF } \\ & \text { PU B L I } \\ & \text { HEALTH }\end{aligned}$ 